\title{
Analisis Kesesuaian dan Variasi Pola Pengambilan Mata Kuliah Terhadap Kurikulum Dengan Teknik Penggalian Proses
}

\author{
Fariz Khairul A, Mahendrawathi ER, S.T., M.Sc., Ph.D \\ Jurusan Sistem Informasi, Fakultas Teknologi Informasi, Institut Teknologi Sepuluh Nopember (ITS) \\ Jl. Arief Rahman Hakim, Surabaya 60111 Indonesia \\ e-mail: mahendrawathi.er@gmail.com
}

\begin{abstract}
Abstrak-Kurikulum adalah sebuah program pembelajaran yang berisi bagaimana alur mata kuliah yang harus diambil oleh seseorang mahasiswa beserta batasan-batasannya. Akan tetapi pada kenyatannya tidak jarang pengambilan mata kuliah mahasiswa tidak mengikuti kurikulum yang sudah ada. Perbedaan antara pengambilan mata kuliah pada kurikulum dengan pengambilan mata kuliah mahasiswa dapat diketahui dengan menggunakan teknik penggalian proses. Penelitian ini menggunakan pengambilan mata kuliah mahasiswa salah satu jurusan di ITS yang sudah lulus dan tidak terkena dampak ekivalensi. Kurikulum yang digunakan adalah kurikulum 2004 dan 2009.

Metodologi pengerjaan dalam penggalian proses ini memiliki empat tahap yang pertama adalah tahap persiapan yaitu dari pemahaman teori sampai pembentukan event log yang ada pada sistem informasi INTEGRA ITS dengan cara melakukan ekstrasi data. Tahap kedua adalah melakukan pembentukan model dengan menggunakan algoritma inductive miner. Tahap ketiga adalah melakukan analisis terhadap model yang dihasilkan yaitu pola pengambilan mata kuliah mahasiswa untuk melihat kesesuaiannya dengan kurikulum yang berlaku. Tahap terakhir adalah rekomendasi dan pembuatan buku tugas akhir.

Hasil dari penggalian proses ini adalah model dari pola pengambilan mata kuliah mahasiswa. Ada enam model yang berbeda yaitu kurikulum 2004 dan 2009, pada setiap kurikulum dipisahkan menjadi tiga yaitu mahasiswa dengan predikat terpuji, sangat memuaskan dan lulus tidak tepat waktu. Setelah dilakukan analisis terhadap keenam model didapatkan hasil bahwa penyebab perbedaan antara kurikulum dengan pola pengambilan mata kuliah mahasiswa adalah terdapat mahasiswa yang mengambil mata kuliah di semester atas dan ada mata kuliah yang diulang kembali.
\end{abstract}

Kata Kunci-Process Mining, Kurikulum, Event log, Petri net.

\section{PENDAHULUAN}

$\mathrm{M}$ ENCETAK lulusan terbaik dan siap memasuki dunia kerja adalah tujuan utama dari seluruh perguruan tinggi. Untuk mencetak lulusan terbaik banyak hal yang harus dipenuhi oleh sebuah perguruan tinggi seperti menyediakan sarana dan prasarana yang baik dan tentunya harus menerapkan proses pembelajaran atau kurikulum yang baik juga.

Kurikulum adalah sebuah program pembelajaran yang berisi bagaimana alur matakuliah yang harus diambil oleh seseorang mahasiswa beserta batasan-batasannya [1]. Batasan tersebut adalah hubungan prasyarat antara satu mata kuliah dengan mata kuliah yang lain. Dengan kata lain kurikulum adalah sebagai panduan mahasiswa untuk mengetahui hal apa yang dipelajari dari awal masuk hingga lulus.

Sejak didirikan pada tahun 2001, salah satu jurusan di Institiut Teknologi Sepuluh Nopember Surabaya telah menghasilkan ratusan lulusan sarjana. Pada rentang waktu itu juga telah menggunakan tiga kurikulum yang berbeda.

Setiap perubahan kurikulum mempunyai dampak terhadap mata kuliah, ada mata kuliah yang ditambahkan atau dihilangkan dan bisa juga sebuah mata kuliah tersebut dilakukan ekivalensi (pemadanan) terhadap mata kuliah pada kurikulum yang baru. Maka dari itu setiap kurikulum memiliki karakteristik dan polanya tersendiri dalam alur mata kuliah yang dijalankan.

Sebelumnya, Institut Teknologi Sepuluh Nopember sudah memiliki sistem yang terintegrasi untuk keperluan akademik dan non akademik yaitu Integra. Sistem ini dapat membantu mahasiswa dalam melakukan proses administrasi perkuliahan seperti mengisikan Formulir Rencana Studi (FRS) dan melihat nilai. Maka dari itu, Integra mempunyai database yang dapat menyimpan seluruh aktivitas mahasiswa selama melakukan kegiatan perkuliahan seperti data mata kuliah yang sudah diambil setiap semester beserta nilainya.

Setiap mahasiswa memiliki polanya tersendiri dalam mengambil sebuah mata kuliah setiap semesternya dan pola tersebut sangat tergantung dari kurikulum yang sedang berjalan. Pola setiap mahasiswa dalam mengambil mata kuliah di setiap kurikulum mungkin memiliki dampak pada ketepatan waktu kelulusan mahasiswa. Salah satu cara untuk mengetahui secara pasti bagaimana pola pengambilan mata kuliah bagi yang lulus tepat dan tidak tepat waktu adalah dengan melakukan Educational Process Mining. Educational Process Mining adalah salah satu bagian ilmu dari process mining yang fokus dalam melakukan penemuan, analisis, dan meningkatkan educational process berdasarkan informasi dari educational event $\log$ [2].

Educational event log adalah sumber data yang digunakan dalam melakukan Educational Process Mining, pada hal ini educational event log yang digunakan adalah data yang berasal dari sistem informasi Integra. Dengan data yang didapatkan dari Integra maka dapat diketahui pola mahasiswa dalam mengambil mata kuliah setiap kurikulumnya. 
Apabila pola pengambilan mata kuliah mahasiswa sudah didapatkan, maka dapat dilakukan analisis lanjutan untuk menemukan temuan - temuan baru dari pola tersebut, contohnya adalah mengetahui mata kuliah apa yang sering diulang oleh mahasiswa setiap kurikulumnya dan berbagai macam variasi pola pengambilan mata kuliah mahasiswa. Hal tersebut menjadi menarik karena sampai saat ini belum ada pemetaan atau dokumentasi khusus mengenai hal tersebut yang dibuat oleh Jurusan tersebut.

\section{URAIAN PENELITIAN}

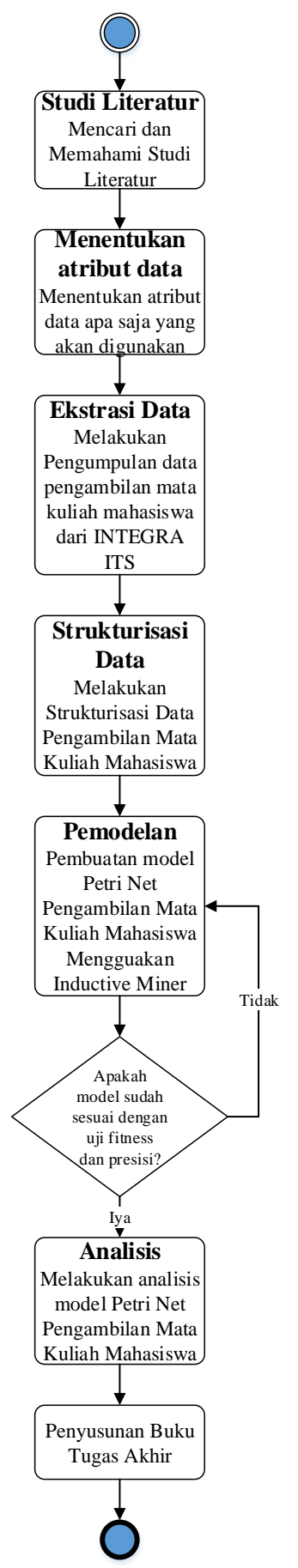

Gambar 1 Metodologi Penelitian

\section{A. Studi Literatur}

Studi literatur merupakan mengumpulkan berbagai macam referensi, diantara lain adalah narasumber, buku, penelitian sebelumnya, dan dokumen yang terkait. Setelah mengetahui topik yang ingin diangkat, langkah selajutnya adalah mencari studi literatur terkait dengan permasalahan yang ada. Studi literatur dibutuhkan untuk memahami dasar-dasar teori yang berhubungan dengan permasalahan.

\section{B. Menentukan Atribut Data yang Akan digunakan}

Setelah mengetahui topik yang akan diangkat dan mengetahui permasalahan beserta batasannya, langkah selanjutnya adalah menentukan atribut data apa saja yang diperlukan untuk melakukan penelitian agar pada saat proses pengumpulan data tidak ada atribut yang dibutuhkan terlewat.

\section{Pengumpulan Data}

Data adalah salah satu pendukung utama dalam terlaksananya penelitian tugas akhir ini. Karena itulah dibutuhkan data yang sesuai dengan topik dan permasalahan yang diangkat. Pada penelitian tugas akhir ini, peneliti mengumpulkan data yang didapatkan dari sistem informasi INTEGRA ITS melalui Biro Akademik Kemahasiswaan Perencanaan ITS. Data yang dikumpulkan adalah event log pengambilan mata kuliah mahasiswa salah satu jurusan di ITS pada sistem informasi INTEGRA.

\section{Strukturisasi Data}

Data yang sudah didapatkan pada aktivitas sebelumnya harus distrukturasi agar menjadi data yang dapat diolah. Karena data yang diekstrasi langsung dari sistem informasi INTEGRA tidak sesuai format yang dibutuhkan, karena itulah data harus disusun kedalam format catatan kejadian (event $\log$ ), yaitu sebagai berikut ini:
a. NRP
b. Nama Mata Kuliah
c. Tahun
d. Semester
e. Timestamp

Kemudian keluaran pada proses ini adalah sebuah file yang berekstensi .mxml yang nantinya dapat dilakukan penggalian proses.

\section{E. Pembuatan model menggunakan algoritma inductive miner}

Setelah mendapatkan data yang telah distruktrisasi kedalam format .mxml, langkah selanjutnya adalah melakukan pola pengambilan mata kuliah dengan menggunakan algoritma inductive miner. Penggalian proses dilakukan dengan menggunakan bantuan tool ProM, dengan menggunakan pilihan algoritma inductive miner.

\section{F. Evaluasi Model}

Setelah melakukan permodelan pada proses pengambilan mata kuliah mahasiswa, langkah selanjutnya adalah melakukan evaluasi pada model. Untuk mengukur performa model dapat dilihat dari dimensi fitness. Langkah ini diperlukan untuk memastikan bahwa model benar-benar dapat mempresentasikan keadaan sesungguhnya. 


\section{G. Melakukan analisis}

Langkah selanjutnya adalah melakukan analisis pada model proses bisnis tersebut. Hal yang ingin dilakukan analisis pada model proses bisnis yaitu:

a. Kesesuaian pola pengambilan kuliah sesuai dengan peta kurikulum

b. Pola pengambilan mata kuliah mahasiswa yang lulus tepat waktu dan tidak tepat waktu pada setiap kurikulum

c. Mencari kemungkinan adanya mata kuliah atau urutan mata kuliah yang mengalami loop

d. Mencari variasi dalam pola pengambilan mata kuliah mahasiswa.

\section{HASIL DAN DISKUSI}

Hasil yang diperoleh dari penggalian proses ini adalah model petri net yang didapatkan dari masukan sistem informasi INTEGRA yang dibentuk menjadi event log. Dari penggalian proses tersebut menghasilkan enam buah petri net yaitu:

- Mahasiswa kurikulum 2004 yang lulus dengan gelar terpuji

- Mahasiswa kurikulum 2004 yang lulus dengan gelar memuaskan

- Mahasiswa kurikulum 2004 yang lulus tidak tepat waktu

- Mahasiswa kurikulum 2009 yang lulus dengan gelar terpuji

- Mahasiswa kurikulum 2009 yang lulus dengan gelar memuaskan

- Mahasiswa kurikulum 2009 yang lulus tidak tepat waktu

\section{A. Analisis mahasiswa kurikulum 2004 dengan predikat terpuji}

Pada kurikulum 2004 terdapat 2 angkatan yang menggunakan kurikulum 2004 secara penuh (tidak terkena dampak ekivalensi) yaitu angkatan 2004 dan 2005. Jumlah kedua angkatan tersebut adalah sebanyak 154 mahasiswa. Kemudian dilakukan filter untuk mencari mahasiswa yang memiliki predikat terpuji atau cumlaude dengan cara mencari mahasiswa yang memiliki IPK diatas 3,5 dan lama waktu studi 3,5 sampai 4 tahun. Setelah melakukan filter tersebut didapatkan 12 mahasiswa yang memiliki predikat terpuji atau cumlaude dan didapatkan 11 varian.

Dari petri net yang dihasilkan dapat disimpulkan bahwa:

- Secara umum pengambilan mata kuliah mahasiswa sudah sesuai dengan pohon kurikulum

- Ada beberapa mahasiswa yang mengambil mata kuliah semester diatasnya seperti KI mata kuliah semester 4 tetapi diambil pada semester 2, mata kuliah BIL adalah mata kuliah semester 8 namun diambil pada semester 7 , dan mata kuliah CRM adalah mata kuliah semester 6 namun diambil semester 4 .

- Mata kuliah yang cenderung diulang oleh mahasiswa adalah mata kuliah MD, mata kuliah tersebut adalah mata kuliah semester 1 dan diulang pada semester 3. Selain itu juga mata kuliah juga cenderung diulang yaitu mata kuliah CRM yang dimana mata kuliah tersebut mata kuliah semester 6 namun diulang pada semester 8 .

- Mata kuliah pilihan diambil biasanya pada semester 7 dan 8.

\section{B. Analisis mahasiswa kurikulum 2004 dengan predikat sangat memuaskan}

Melakukan filter untuk mencari mahasiswa yang memiliki predikat terpuji atau cumlaude dengan cara mencari mahasiswa yang memiliki IPK diatas 3 dan lama waktu studi 3,5 sampai 4 tahun. Setelah melakukan filter tersebut didapatkan 81 mahasiswa yang memiliki predikat sangat memuaskan dan didapatkan juga varian sebanyak 80 .

Dari petri net yang dihasilkan dapat disimpulkan bahwa:

- Secara umum pengambilan mata kuliah mahasiswa sudah sesuai dengan pohon kurikulum.

- Ada beberapa mahasiswa yang mengambil mata kuliah semester diatasnya seperti KI mata kuliah semester 4 tetapi diambil pada semester 2, mata kuliah BIL adalah mata kuliah semester 8 namun diambil pada semester 7 . Mata kuliah CRM dan EP diambil pada semester 4 sedangkan mata kuliah tersebut seharusnya pada semester 6.

- Mata kuliah yang cenderung diulang oleh mahasiswa adalah mata kuliah FD 1 dan KL 1, mata kuliah tersebut adalah mata kuliah semester 1 dan diulang pada semester 3. Selain itu juga mata kuliah juga cenderung diulang yaitu mata kuliah KL 2 yang dimana mata kuliah tersebut mata kuliah semester 2 namun diulang pada semester 4 .

- Mata kuliah pilihan diambil biasanya pada semester 7 dan 8.

C. Analisis mahasiswa kurikulum 2004 yang lulus tidak tepat waktu.

Melakukan filter untuk mencari mahasiswa yang lulus tidak waktu dengan lama waktu studi 4,5 tahun. Setelah melakukan filter tersebut didapatkan 13 mahasiswa yang lulus tidak tepat waktu dan didapatkan juga varian sebanyak 14.

Dari petri net yang dihasilkan dapat disimpulkan bahwa:

- Pola pengambilan mahasiswa yang lulus tidak tepat waktu pada kurikulum 2004, cenderung selalu mengambil atau menambah mata kuliah dari semester diatasnya. Mata kuliah yang cenderung diambil atau ditambah mahasiswa adalah BIL.

- Pada pola pengambilan mahasiswa yang lulus tidak tepat waktu pada kurikulum 2004, mata kuliah yang cenderung diulang adalah:

$\circ$ FD 1

$\circ \mathrm{KL} 1$

$\circ$ TA

- Penyebab terlambatnya waktu kelulusan mahasiswa pada kurikulum 2004 adalah disebabkan oleh TA yang tidak selesai dalam satu semester.

- Mata kuliah pilihan diambil pada semester 6 dan 7. 


\section{Analisis mahasiswa kurikulum 2009 dengan predikat terpuji}

Pada kurikulum 2009 terdapat 2 angkatan yang menggunakan kurikulum 2009 secara penuh (tidak terkena dampak ekivalensi) yaitu angkatan 2009 dan 2010. Jumlah kedua angkatan tersebut adalah sebanyak 227 mahasiswa. Kemudian dilakukan filter untuk mencari mahasiswa yang memiliki predikat terpuji atau cumlaude dengan cara mencari mahasiswa yang memiliki IPK diatas 3,5 dan lama waktu studi 3,5 sampai 4 tahun. Setelah melakukan filter tersebut didapatkan 61 mahasiswa yang memiliki predikat terpuji atau cumlaude dan didapatkan juga varian sebanyak 61.

Dari petri net yang dihasilkan dapat disimpulkan bahwa:

- Pola pengambilan mahasiswa dengan predikat terpuji pada kurikulum 2009, cenderung selalu mengambil atau menambah mata kuliah dari semester diatasnya. Mata kuliah yang cenderung diambil atau ditambah mahasiswa adalah:

a. KW, seharusnya diambil pada semester 6 tetapi diambil pada semester 2

b. ST, seharusnya diambil pada semester 4 tetapi diambil pada semester 3

c. TKATI, seharusnya diambil pada semester 7 tetapi diambil pada semester 5

d. PETI, seharusnya diambil pada semester 8 tetapi diambil pada semester 6

e. BI, seharusnya diambil pada semester 7 tetapi diambil pada semester 6

f. EP, seharusnya diambil pada semester 8 tetapi diambil pada semester 7

- Pada pola pengambilan mahasiswa dengan predikat terpuji pada kurikulum 2009, tidak ada kecendurungan mata kuliah yang diulang.

- Mata kuliah pilihan diambil pada semester 6 dan 7.

\section{E. Analisis mahasiswa kurikulum 2009 dengan predikat} sangat memuaskan

Melakukan filter untuk mencari mahasiswa yang memiliki predikat sangat memuaskan dengan cara mencari mahasiswa yang memiliki IPK diatas 3 dan lama waktu studi 3,5 sampai 4 tahun. Setelah melakukan filter tersebut didapatkan 45 mahasiswa yang memiliki predikat sangat memuaskan dan didapatkan sebanyak 45 varian.

Dari petri net yang dihasilkan dapat disimpulkan bahwa:

- Pola pengambilan mahasiswa dengan predikat sangat memuaskan pada kurikulum 2009, cenderung selalu mengambil atau menambah mata kuliah dari semester diatasnya. Mata kuliah yang cenderung diambil atau ditambah mahasiswa adalah:

a. KWN, seharusnya diambil pada semester 6 tetapi diambil pada semester 2

b. ST, seharusnya diambil pada semester 4 tetapi diambil pada semester 3

c. PETI, seharusnya diambil pada semester 8 tetapi diambil pada semester 6

d. BI, seharusnya diambil pada semester 7 tetapi diambil pada semester 6 e. EP, seharusnya diambil pada semester 8 tetapi diambil pada semester 7

f. TECH, seharusnya diambil pada semester 5 tetapi diambil pada semester 4

g. MITI, seharusnya diambil pada semester 6 tetapi diambil pada semester 4

- Pada pola pengambilan mahasiswa dengan predikat sangat memuaskan pada kurikulum 2009, tidak ada kecenderungan mata kuliah yang diulang.

- Mata kuliah pilihan diambil pada semester 5, 6, dan 7.

\section{F. Analisis mahasiswa kurikulum 2009 yang lulus tidak tepat} waktu

Melakukan filter untuk mencari mahasiswa yang lulus tidak waktu dengan lama waktu studi 4,5 tahun. Setelah melakukan filter tersebut didapatkan 69 mahasiswa yang lulus tidak tepat waktu dan didapatkan juga varian sebanyak 69.

Dari petri net yang dihasilkan dapat disimpulkan bahwa:

- Pola pengambilan mahasiswa yang lulus tidak tepat waktu pada kurikulum 2009, cenderung selalu mengambil atau menambah mata kuliah dari semester diatasnya. Mata kuliah yang cenderung diambil atau ditambah mahasiswa adalah:

a. KW, seharusnya diambil pada semester 6 tetapi diambil pada semester 2

b. ST, seharusnya diambil pada semester 4 tetapi diambil pada semester 3

c. PETI, seharusnya diambil pada semester 8 tetapi diambil pada semester 6

d. EP, seharusnya diambil pada semester 8 tetapi diambil pada semester 7

e. TECH, seharusnya diambil pada semester 5 tetapi diambil pada semester 4

f. MITI, seharusnya diambil pada semester 6 tetapi diambil pada semester 4

- Pada pola pengambilan mahasiswa yang lulus tidak tepat waktu pada kurikulum 2009, mata kuliah yang cenderung diulang adalah:

○ DM

$\circ$ PS

○ TA

- Penyebab terlambatnya waktu kelulusan mahasiswa pada kurikulum 2009 adalah disebabkan oleh tugas akhir yang tidak selesai dalam satu semester.

- Mata kuliah pilihan diambil pada semester 6 dan 7.

\section{KESIMPULAN/RINGKASAN}

\section{A. Kesimpulan}

Kesimpulan yang dapat diambil dari penelitan tugas akhir ini adalah sebagai berikut.

1. Dalam tugas akhir ini telah dilakukan pemodelan dan analisis pengambilan mata kuliah mahasiswa dengan langkah sebagai berikut:

a. Melakukan ekstrasi data pengambilan mata kuliah mahasiswa salah satu jurusan di ITS angkatan 2004, 2005, 2009, dan 2010 dari sistem informasi INTEGRA 
b. Melakukan strukturisasi data agar bisa digunakan untuk melakukan penggalian proses

c. Membuat model petri net dengan menggunakan algoritma inductive miner. Terdapat enam model yang dihasilkan yaitu:

○ Mahasiswa dengan predikat terpuji kurikulum 2004

- Mahasiswa dengan predikat sangat memuaskan kurikulum 2004

- Mahasiswa lulus tidak tepat watu kurikulum 2004

- Mahasiswa dengan predikat terpuji kurikulum 2009

- Mahasiswa dengan predikat sangat memuaskan kurikulum 2009

- Mahasiswa lulus tidak tepat watu kurikulum 2009

d. Melakukan pengujian dimensi fitness pada setiap model petri net untuk memastikan model yang dihasilkan sudah sesuai

e. Melakukan analisis pada setiap model petrinet untuk mencari urutan mata kuliah pada setiap kurikulumnya.

2. Dari hasil pemodelan urutan pengambilan mata kuliah mahasiswa didapatkan variasi urutan pengambilan mata kuliah mahasiswa yaitu:

a. Sebanyak $92 \%$ dari keseluruhan mahasiswa dengan predikat terpuji pada kurikulum 2004 memiliki variasi urutan pengambilan mata kuliah yang berbeda

b. Sebanyak $99 \%$ dari keseluruhan mahasiswa dengan predikat sangat memuaskan pada kurikulum 2004 memiliki variasi urutan pengambilan mata kuliah yang berbeda.

c. Seluruh mahasiswa yang lulus tidak tepat waktu pada kurikulum 2004 memiliki variasi urutan pengambilan mata kuliah yang berbeda.

d. Seluruh mahasiswa pada kurikululum 2009 baik yang memiliki predikat terpuji, sangat memuaskan, ataupun lulus tidak tepat waktu memiliki urutan mata kuliah yang berbeda-beda.

3. Pada tahun pertama mahasiswa dengan kurikulum 2004 cenderung mengambil mata kuliah di semester atasnya dibanding dengan kurikulum 2009. Hal ini terlihat dari model pengambilan mata kuliah kurikulum 2004 dimana pada tahun pertamanya lebih banyak alternatif mata kuliah yang ditempuh dengan urutan yang tidak spesifik dibandingkan dengan kurikulum 2009.

4. Untuk tahun kedua dan seterusnya mahasiswa dengan kurikulum 2009 cenderung lebih banyak mengulang atau mengambil mata kuliah semester atas dibanding dengan kurikulum 2004. Hal ini terlihat dari model kurikulum 2009 untuk tahun kedua dan selanjutnya lebih banyak alternatif mata kuliah yang ditempuh dengan urutan yang tidak spesifik dibanding dengan kurikulum 2004.

5. Model urutan mata kuliah mahasiwa yang lulus tidak tepat waktu baik pada kurikulum 2004 dan kurikulum 2009 hampir sama dengan urutan mata kuliah yang lulus tepat waktu. Hal yang paling membedakan pada model adalah terdapat pengulangan atau looping pada mata kuliah tugas akhir.

\section{B. Saran}

Saran yang dapat diberikan dari penelitan tugas akhir ini adalah sebagai berikut.

1. Timestamp pada event log dapat dibuat lebih detail, jadi timestamp-nya dibedakan pada saat pengambilan mata kuliah dalam satu semester

2. Memasukan aktifitas baru seperti melakukan drop mata kuliah di tengah semester untuk memperdalam hasil analisis

3. Sebelum menentukan algoritma yang digunakan, bandingkan terlebih dahulu antar algoritma untuk melihat algoritma mana yang sesuai dengan event $\log$ yang dimiliki.

\section{DAFTAR PUSTAKA}

[1] J. M. v. d. Werf, E. Verbeek and W. M. v. d. Aalst, "Context-Aware Compliance Checking," Business Process Management, vol. 7481, pp. 98-113, 2012.

[2] S. P. D. N. Gehrke and D.-W.-I. Michael Werner, "Process Mining," 2010. [Online]. Available: https://www.wiso.unihamburg.de/fileadmin/wiso_fs_wi/Publikationen/Michael/Gehrke_und_ Werner_-_2013_-_Process_Mining_Pre-print_Version.pdf. [Accessed 15 12 2015]. 